Ben Barman was lucky to find himself with the Penrose family. He adjusted well to Canada and did not want to return to Britain when the moment came in 1943. Fearful of the journey home and the possibility of being bombed, he also did not wish to attend a British boarding school. His parents assured him he would not be sent away and then reneged upon this promise. Re-integrating into Britain was no easy task.

Margaret Penrose is much more articulate than her charge. Perhaps because she was a trained medical doctor, she fretted over Ben's delayed puberty, treating him with iodine, and writing to his mother about the disappointing development of secondary sexual characteristics, especially focussing on the smallness of his testicles. Her letters expose expert ideas about normalcy, sexuality, and masculinity, and anxiety about the size of male sexual organs. Perhaps historians of sexuality might draw further upon these letters, placing them into a broader context, about medicalization of the timing of puberty and the imposition of rigid expectations on childhood sexual development.

This volume has a very helpful annotated bibliography on evacuated children's experiences, but it also has a few annoying flaws. In some places, better organization would have created a smoother read. There are also some typographical and grammatical errors and odd repetitions of phrases. Nonetheless, the book offers educational historians direct access to a child's own voice, his foster mother's commentary, and valuable contextual analysis.

Isabel Campbell

Directorate of History and Heritage National Defence Headquarters ${ }^{2}$

Theodore Michael Christou

Progressive Rhetoric and Curriculum: Contested Visions of Public Education in Interwar Ontario

Abingdon, UK: Routledge, 2018. 182 pp.

Many historians and educationalists will freely admit that any effort to try to define the term "Progressivism" may quickly lead one down a rabbit hole of confusion and vague delineations. Certainly, Herbert Kliebard holds enormous sway when, in his iconic book The Struggle for the American Curriculum 1893-1958 (1987), he argues that the term itself should be seen as useless and troublesome. Theodore Christou, in trying to come to grips with the meaning of the Progressive movement for education in Ontario, has been forced to face this possibility over the past decade of his research. His internal debate is evident in the introduction of his most recent contribution Progressive Rhetoric and Curriculum: Tongue-in-cheek, he asks the lamentable question "Who is not a progressive reformer, anyway?" (1) Rather than accepting this

2 The review represents the reviewer's personal opinions and not those of National Defence. 
defeatist impulse, however, he chooses instead to pull apart doggedly the diaphanous substance of the term to examine methodically its constituent components.

The most evident feature I found in Christou's latest offering was the way he corralled the study with carefully selected and distinct boundaries as he wrestles meaning from the primary sources he uses. How is this different from his earlier attempt to deal with the term "Progressive" in Progressive Education: Revisioning and Reframing Ontario's Public Schools, 1919-1942 (2012)? As I read one and re-read the other, I could not help but compare the two books. And in so doing, my mind wandered back to the 1960s classic film, Easy Rider. In it, the dissolute ACLU lawyer George Hanson makes a significant distinction when confronting variations in the term 'Freedom': “ . . . talkin' about it and bein' it — that's two different things." And, I believe that this is the real difference between Christou's two works. As hinted in its title, his recent study chooses to remain in the arena of the rhetorical, winnowing out what has been actually done in the province (a focus of his previous book) from what has been said about Progressivism (the focus of the present one).

A second differentiation that Christou makes for his recent study is the source of inspiration for his theoretical lens. Like his previous work, he does adapt three beliefs (which he now calls domains) that John Dewey deemed common to Progressive educators: First, that the individual student rests at the centre of the educational enterprise; second, that learning should be an active process; and third that schools should reflect contemporary society. However, he now adds three new themes (drawn from Kleibard's work) to drive his study forward: a) child study/ developmental psychology; b) social efficiency; and c) social meliorism. With a focus on this latter threepiece set, Christou sets out to test Kliebard's model in the Ontario context, devoting a chapter to each theme which he scrutinizes with Dewey's three domains. In so doing, Christou shows the many and surprising variations of Progressivism (frequently at odds with one other), both in Ontario and in the movement itself.

Preconceived notions of the term "Progressivism" and the usual stock characters are confronted right from the outset of this examination, and challenges carry on throughout the book. Of course, it was no surprise that, in going down the first thematic path (child study/development psychology) in Ontario, Christou chose to focus on Dr. William Blatz. As the founding director of the Institute of Child Study in Toronto, he was the undisputed leader of this area of educational research during the interwar period. However, trying to examine Blatz as a way to get a clearer definition of Progressivism is certainly not for the faint of heart. While he did espouse certain Progressive aphorisms - I have never been able to neglect the many hallmarks that made this enigmatic figure appear as a behaviourist at the same time - to me he was as much a protégé of John Watson as he was of John Dewey. However, the strength of Progressive Rhetoric and Curriculum is to show that a complex figure like Blatz need not be pinned down to an absolute either/or position when it comes to Progressivism. So many have tried, and wound up defining an elephant like a piece of rope. Instead, Christou describes, in more nuanced terms, the gradients of Blatz's connection, based on an examination of his rhetoric.

In Christou's dealing with the inhabitants of the other two new themes explored 
in this book (efficiency and meliorism), the reader is once again reminded just how deeply intertwined Progressivism can be with other seemingly unrelated circles. While I would not hasten to call Franklin Bobbitt a poster child for the term (at least by my definition), Christou shows how, under certain conditions, the founder of scientific management in curriculum fits under the Progressive umbrella. By the same token, Christou also displays how a paragon of Progressivism like C. C. Goldring could, by his own admission, opt for more traditional educational techniques. By the time the book reaches its climax - a case study of one of Ontario's interwar Deputy Ministers (Duncan McArthur) — the reader is eager to see where in Christou's typology this self-professed Progressivist fits.

Having my own favourites of this time period, I was disappointed that Christou did not give more play to the more garden-variety examples of Ontario Progressives such as Peter Sandiford, Stanley Watson, or John Althouse. However, this seemed to be the whole point of Christou's book. In a bid to avoid pat labels, he chose to come to terms with Progressivism as Blatz did with intelligence quotient (IQ) testing: In its function rather than its form. Christou's definition does not lie solely in listing a series of appropriate die-hards or dogmas. Instead, meaning is derived from the pure rhetoric found in the Ontario sources, no matter the origin. In that way, Christou answers the question "Who is not a progressive reformer, anyway?" The implied response must be "Nobody, given the right context."

Kurt Clausen

Nipissing University

Elizabeth Todd-Breland

\section{A Political Education: Black Politics and Education Reform in Chicago since the 1960s}

Chapel Hill: University of North Carolina Press, 2018. 344 pp.

The cover of $A$ Political Education shows teachers protesting unfair conditions in public schools in 2012. Page after page, the book inside reveals a palimpsest of decades of similar protests and organizing since the 1960s. Elizabeth Todd-Breland chronicles the politics of Black achievement in Chicago - a phrase referring to the wide array of strategies that activists used to improve schooling conditions and educational opportunities for Black students in the midwestern city.

Following activists and organizations that fought relentlessly for Black Chicagoans, Todd-Breland tackles pivotal moments of the history of education such as desegregation, community control, Black Power schools, teacher movements and reforms around school choice. Actors in this profoundly human story are Black education reformers, and Todd-Breland reclaims the term "reformer" (6) to underline how the educational history literature has falsely equated it with white male Progressive Era planners. 